\title{
Assessment of postharvest loss along potato value chain: the case of Sheka Zone, southwest Ethiopia
}

\author{
Benyam Tadesse ${ }^{1 *}$, Fayera Bakala ${ }^{2}$ and Lamirot W. Mariam ${ }^{3}$
}

\begin{abstract}
Background: Ethiopia has possibly the highest potential for potato production than any country in Africa. Postharvest loss (20-25\%) is one of the major problems in the potato production. Therefore, this study was conducted with the objective of assessing postharvest losses along potato value chain actors and identifying its determinants in the study area.

Results: The descriptive result indicated that the quantity of postharvest losses at producer, local trader, wholesaler and retailer level was $21.724,1.838,3.406$ and $4.07 \mathrm{~kg} / \mathrm{qt}$, respectively. The average gross margin with loss of producers, local traders, wholesalers and retailers was 6464.70, 282,169.89, 219,644.61 and 345,826.36 Birr, respectively, which is less than the average gross margin without loss (10,146.12, 284,015.83, 221,274.69 and 352,986.62 Birr, respectively). Distance to the nearest market, area allocated for potato and total output determine postharvest loss positively, and sex, experience, family size of working age, selling price and access to credit determine postharvest loss negatively.
\end{abstract}

Conclusion: In the study area, lack of storage facilities for potato was raised by farmers and other actors as a priority problem. Intervention of government from input supply until the end consumers is paramount and preparing storage mechanism is a must.

Keywords: Gross margin, Multiple linear regressions, Postharvest loss, Potato

\section{Background}

Achieving food security continues to be a challenge as it is affected by a complexity of factors [1-3]. Increasing the food availability is therefore not only increasing the productivity in agriculture, but also a need to lower the losses [4-6]. Food losses after harvest until the food reach the consumer are significant [7]. A large amount of food and products are not reaching the consumer particularly due to postharvest losses $[4,7]$ during harvesting, handling, transporting, storage, processing, packaging and distribution. Postharvest losses reduce the availability of food crops and income that could be generated by selling these products; thus in terms of quantity they are linked to food security [7-9]. According to FAO

\footnotetext{
*Correspondence: tadessebenyam7@gmail.com

${ }^{1}$ College of Agriculture and Natural Resources, Department of Agro

Economics, Mizan-Tepi University, Mizan-Aman, Ethiopia

Full list of author information is available at the end of the article
}

[10], postharvest losses in developing countries can range from 15 to $50 \%$.

Potato (Solanum tuberosum L.) is the fourth most important food crop in the world on the basis of production after maize, rice and wheat with annual production accounts of nearly 300 million tonnes [11]. Out of these, over half of production occurs in developing countries [12]. During the production year of $2015 / 2016$, it ranks first in area coverage and third in both total production and productivity among the root crops grown in Ethiopia [13]. It produces considerably more energy and protein than cereals [14]. It is also the fastest growing staple food crop and source of cash income for smallholder farmers in Ethiopia [15, 16]. It has a short cropping cycle and a large production per unit area in a given time. It provides more nutritious food per land unit in less time and often under more adverse condition than other food crops due to its efficient water use. It is one of the most efficient 
crops in converting natural resources, labor and capital into a high-quality food. Potato provides more food per unit area than any other major staple crop. They are the perfect food and one of the few that can actually sustain life on its own. Thus, it has significant impact on providing nutrition to families, increasing household income and providing surplus to the wider market [17].

Ethiopia has possibly the highest potential for potato production than any country in Africa with $70 \%$ of the 13.5 million ha of arable land suitable for potato cultivation. Over one million highland farmers could grow potatoes in Ethiopia. Two of the three known agroecologies Woyina Dega (1500-2300 masl) and Dega (above 2300 masl) exhibit the best out-grower potato production [18]. However, the potato is widely regarded as a secondary non-cereal crop in part because it has never reached the potential that it has in supporting food security. It is estimated that $296,577.59$ ha is now planted and $36,576,382.69$ qt production annually [13]. Hence, it contributes toward efforts of ensuring food and nutrition security. In Ethiopia, potato is becoming a prominent source of income since the crop is the most important cash crop for smallholder farmers in the mid-altitude and highland areas of the country [19, 20]. Ethiopia has a much higher potential to increase agricultural production of the crop through use of improved seeds and undertaking technological innovation that facilitate the management and reduce postharvest losses [17, 21].

Postharvest loss $(20-25 \%)$ is one of the major problems in the potato production. This entails that significant loss is incurred to the small holders that could have helped in nutrition, food security and income generation [22]. Potato yield productivity has increased far more than 24 tons per hectare due to adoption of new varieties [17]. However, postharvest loss reduction efforts have not been tailored well. Harvesting loss reduction helps increasing income, achieve food security and subsequent storage lose reduction [23]. Thus, to reduce postharvest losses, appropriate technologies should be developed and promoted. With the reduction in postharvest losses by $50 \%$, food availability would be increased by $20 \%$ without cultivating an additional hectare of land for increasing crop yield [24]. Until recently, knowledge of postharvest handling of fruits and vegetables such as improved storage, packaging, transport and handling techniques in developing regions like southwest Ethiopia was virtually nonexistent for perishable crops in most areas, thus allowing for considerable losses of produce. Postharvest losses have been highlighted as one of the determinants of the food problem [25]. According to Oyekanmi [26], postharvest loss prevention technology techniques becomes paramount as more produce is transported to non-producing areas to supply the growing population as well as storing for longer period to obtain a yearround supply. Despite the remarkable progress made in increasing world food production at the global level, approximately half of the population in the third world does not have access to adequate food supplies. There are many reasons for this; one of which is food loss occurring in the postharvest and marketing systems. Evidence suggests that these losses tend to be highest in countries where the need for food is greatest [25]. Food supply can be improved either by increase in production or more importantly, reduction in loss. Since many researches show that great effort is being made in the area of food production, especially in the developing countries, the decline in food production therefore can be traced to postharvest losses. Reduction in postharvest losses therefore will increase food availability, hence alleviation of food shortage problems. Managing the effect of postharvest losses has the potential tendency to reduce the effect of the efforts put into production and increase marketing efficiency [27]. Therefore, this study seeks to examine postharvest losses along potato value chain, underlying factors that contribute to the massive postharvest losses, taking into consideration the postharvest handling practices and how it affects the income of potato farmers in southwest Ethiopia.

\section{Methods}

\section{Description of study area}

This study was conducted in southwest Ethiopia, Masha District of Sheka Zone. Masha is one of the three districts in Sheka Zone of Southern Nation Nationalities and Peoples Region (SNNPR), which is located at $677 \mathrm{~km}$ to southwest of Addis Ababa. Sheka Zone is known by its dense forest coverage, and the agroecology is $70 \%$ midaltitude, 20\% high altitude and 10\% low altitudes. The zone composes three districts, viz., Yeki, Andracha and Masha. Its altitude ranges from 950 to $3300 \mathrm{~m}$ above sea level. Mean rainfall level is more than $2000 \mathrm{~mm}$. Regarding rainfall distribution, high rainfall occurs at June, July, August, September, medium at October, November, March, low at April and May and little/no at December and January. Major crops grown in the area are enset, sorghum, maize, coffee, potato, field pea, fava bean, wheat, barley, haricot bean and teff. Agricultural farming system is enset-production-based farming system. Total land coverage of the area is $217,527.15$ hectare and from this $26 \%$ is for cultivation, $41.3 \%$ plantations, $2.24 \%$ pasture, $8.96 \%$ cultivable and $3.5 \%$ uncultivable land. The area was selected for this study due to exceptionally high potential for potato production in the southwestern part of Ethiopia. The district is composed of 19 rural kebeles; among these the study was conducted in 3 kebeles, viz., Gatimo, Atiso and Shibo, as indicated in Fig. 1. 


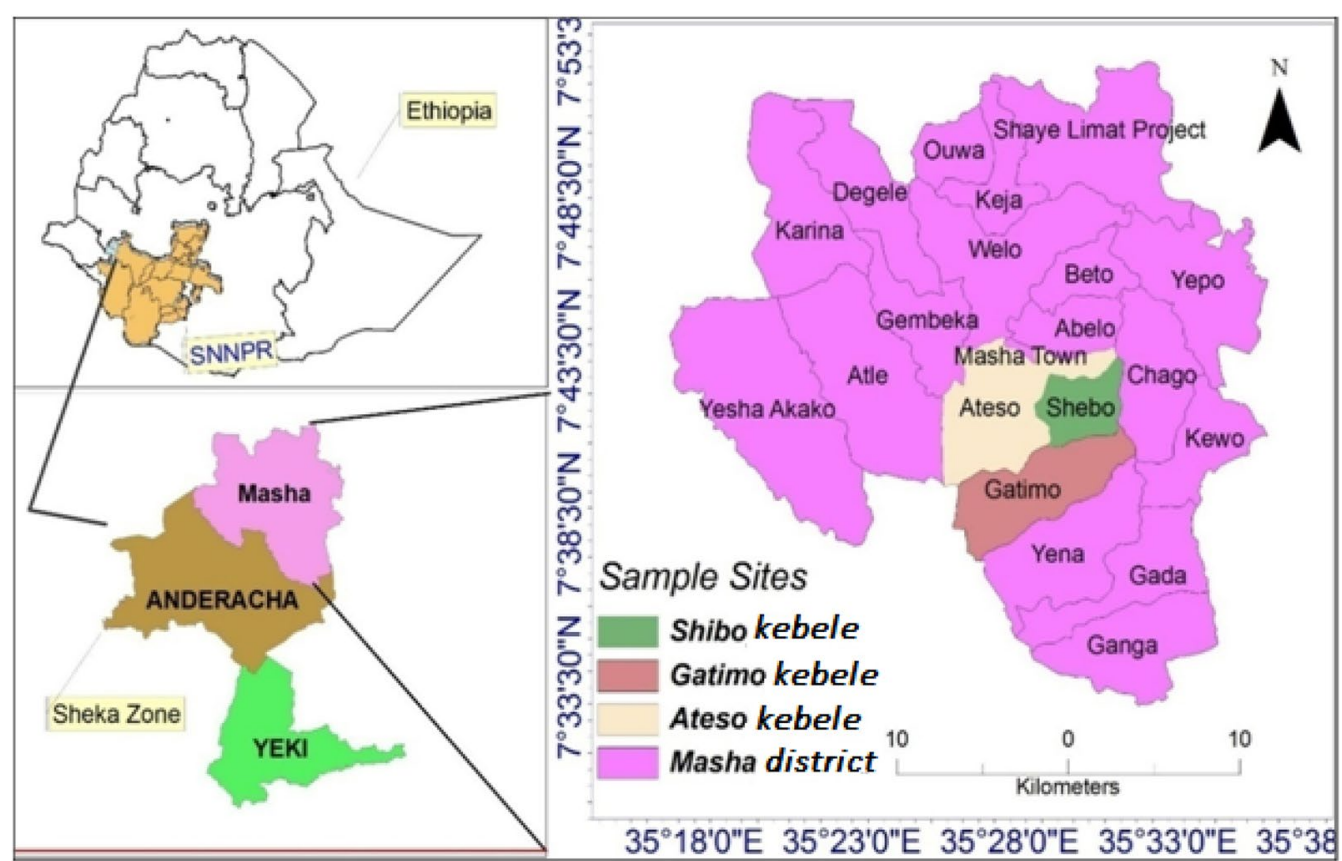

Fig. 1 Map of study area

\section{Data source and instruments}

In this study, both primary and secondary data sources were used. Different approaches of primary data collection methods were used. This includes survey, focus group discussions, key informant interviews, field observations and market assessments. Individuals from agricultural development and cooperative offices as well as the local people who have knowledge and experience about potato production and marketing were selected as key informants and interviewed on the issues related to potato production and marketing.

\section{Sampling procedure}

In this study, three-stage sampling technique was used. In the first stage, high-quantity potato-producing district was purposively selected. At the second stage, among the 19 rural kebeles of district, 3 kebeles were again purposively selected based on the intensity of production and marketing of potato. In the third stage, household heads producing potato were selected randomly from the total potato producers from three kebeles. The sample size was determined by rule of thumb suggested by Greene [28] $\mathrm{N} \geq 50+8 \mathrm{~m}$, where $\mathrm{N}$ is sample size and " $\mathrm{m}$ " is the number of explanatory variables. The sample size was determined by proportional to total population within three kebeles. Thus, using the total potato producers household list 193 producers were selected proportionally to total population of three kebeles (Tables 1, 2).
Table 1 Sample size of producers. Source: own survey, 2017

\begin{tabular}{lllll}
\hline Kebeles & $\begin{array}{l}\text { Total number } \\
\text { of potato producers } \\
\text { (population) }\end{array}$ & Sample size & Percent & Cum. \\
\hline Gatimo & 116 & 60 & 31.09 & 31.09 \\
Shibo & 108 & 56 & 29.02 & 60.1 \\
Atiso & 149 & 77 & 39.9 & 100 \\
Total & 373 & 193 & 100 & \\
\hline
\end{tabular}

Table 2 Sample size of traders. Source: own survey, 2017

\begin{tabular}{lllll}
\hline Market place & $\begin{array}{l}\text { Commission } \\
\text { agents }\end{array}$ & Traders & Wholesalers & Retailers \\
\hline Mashatown & 5 & 7 & 7 & 5 \\
\hline
\end{tabular}

Regarding other value chain actors sample size, 7 local traders, 5 wholesalers and 8 retailers were selected by snowball techniques.

\section{Data analysis}

Data were analyzed by descriptive statistics, gross margin and ordinary least squares regression analysis. Descriptive statistics such as frequency distribution, percentages and mean were used in analyzing socioeconomic characteristics of respondents and quantity of potato lost at each value chain actor's level, while gross margin analysis 
was used to estimate the profit made by potato value chain actors in the study area. The gross profit of a business is estimated as the difference between the total sales and variable cost incurred.

$$
\mathrm{GM}=\mathrm{TR}-\mathrm{TVC},
$$

where $G M$ is gross margin and $T R$ is total revenue [value of output (amount realized from the sale of potato)]. It was obtained by multiplying the quantity of potato sold by the unit selling price. TVC is total variable cost which includes cost of all inputs (preharvest and postharvest labor wage, transportation costs and other input costs).

\section{Econometric model}

Econometrically, multiple linear regression model was used to examine the relationship between postharvest loss of potato and explanatory variables. The general form of multiple linear regressions is:

$$
\begin{aligned}
& Y=f\left(X_{1}, X_{2}, X_{3}, X_{4} \ldots X_{k}\right) \\
& Y=\beta_{\mathrm{o}}+\beta_{1} X_{1}+\beta_{2} X_{2}+\beta_{3} X_{3}+\cdots+\beta_{4} X_{k}+\varepsilon i
\end{aligned}
$$

$Y$ represents postharvest loss and $X_{1}, X_{2}, X_{3}, X_{4} \ldots X_{k}$ represents independent or explanatory variables, and $\varepsilon i$ is the disturbance factor. It is possible to write the function as:

Quantity of potato lost $=f$ (Sex, Age, farming experience, Education_level, Distance to nearest market, FMSZ_working_age, Area allocated for potato production, total_output, selling price, local_seed, Improved seed, CREDITS and training). Based on this quantity lost function of potato, the econometric model for quantity of potato lost was written as:

$$
\begin{aligned}
& \text { Quantity of potato lost } \\
& \begin{aligned}
= & \beta_{\mathrm{o}}+\beta_{1} \mathrm{Sex}+\beta_{2} \mathrm{Age}+\beta_{3} \text { experience }+\beta_{4} \text { Education } \\
& +\beta_{5} \text { Distance }+\beta_{6} \mathrm{FMSZ}+\beta_{7} \mathrm{AOLP}+\beta_{8} \text { total_output } \\
& +\beta_{9} \text { sellingprice }+\beta_{10} \text { local_seed }+\beta_{11} \text { Improved seed } \\
& +\beta_{12} \text { CREDITS }+\beta_{13} \text { DIUGETTR }+\varepsilon i
\end{aligned}
\end{aligned}
$$

where $\beta_{\mathrm{o}}=$ intercept term.

\section{Results}

\section{Socio-demographic characteristics of respondents}

The average age of interviewed respondents was 37.6632 years, while the average family size of the respondents was 6 in numbers. The education levels of respondents in the study areas were generally low (mean of 5.3990 years of schooling). On average, producer households had 7.0415 years of experiences in potato production and marketing. The mean distance from the nearest market center of producers in the study area was $5.5026 \mathrm{~km}$. From the total land owned by the respondent, the land allocated for potato production is $0.55 \mathrm{ha} /$ household, that means $27.94 \%$ of total.

From the total respondents, only $2 \%$ were Females and the rest were males. About $96.4 \%$ of studied respondents were married, while the remaining were not married (Table 3). Only half of producers had access to market information. From the total respondents, $2.6 \%$ of respondents had access to credit, while the rest $97.4 \%$ of respondents had no access of credit. Concerning other services, about $60 \%$ of producers had access to extension (Table 4).

Table 3 Demographic characteristics of respondents for continuous variables. Source: Own survey, 2017

\begin{tabular}{lcc}
\hline Variables & Mean & SD \\
\hline Age & 37.6632 & 10.06259 \\
Education level & 5.399 & 3.17402 \\
Distance from market & 5.5026 & 2.72742 \\
Experience & 7.0415 & 4.34554 \\
Total family size & 6.8622 & 2.05808 \\
Family size in working age & 3.4218 & 1.48497 \\
\hline
\end{tabular}

Table 4 Socioeconomic characteristics of producers (categorical variables). Source: own survey, 2017

\begin{tabular}{llcl}
\hline Variables & Description & Frequency & Percent \\
\hline Access to extension service & Yes & 116 & 60 \\
& No & 77 & 40 \\
Access to market information & Yes & 96 & 50 \\
& No & 97 & 50 \\
Sex & Male & 190 & 98 \\
\multirow{4}{*}{ Access to credit } & Female & 3 & 2 \\
& Yes & 5 & 3 \\
& No & 188 & 97 \\
\hline
\end{tabular}




\section{Socioeconomic characteristics of traders}

In this study, trader refers to local traders, retailers and wholesalers. As indicated in Table 3, the average age of local traders, retailers and wholesalers was 31.43, 29.13 and 35 years, respectively. Local traders, retailers and wholesalers averagely have 4 family members. Averagely, wholesalers were more experienced ( 4.2 years) as compared to local traders (2.71 years) and retailers (2 years). But in education level retailers were more educated than wholesalers. The initial working capital of local traders, retailers and wholesalers was $6500.14,{ }^{1} 359.38$ and 21,928 Birr, respectively, but the respective current working capital was 59,000, 3410.34 and 65,034 Birr. Table 6 shows all traders and wholesalers were male, while $63 \%$ of retailers were female and the rest were males. All traders, retailers and wholesalers had market information; however, none of traders had access to credit sources (Table 5).

According to the survey result in Table 6, all traders responded that they have access to market information. All local traders and wholesalers were males only, but $38 \%$ of retailers were females. All local traders, wholesalers and retailers responded that they have no access for credit service in the study area.
Assessment of postharvest loss along potato value chain The descriptive result indicated that the mean value of the amount of potato postharvest loss at producer level was 9.31 qt per year per household which means $21.72 \%$. When we estimate it in ETB, one household lose $3683.11 \mathrm{Br}^{1}$ per year due to potato postharvest loss (Fig. 2).

Next to producer, postharvest loss of potato was higher at retailer level. The postharvest loss assessment of local traders revealed that the quantity of potato lost in quintal per household was $3.34 \mathrm{qt}$ which accounts $0.59 \%$. It indicated that local traders lose 1324.64 ETB per household per year due to potato postharvest loss. Wholesalers lose 2.5 qt per household per year due to postharvest loss which estimated $0.65 \%$. It indicated that one wholesaler lose 1630.1 ETB per year. Retail level losses were about 1.92 percent of the total produce of potato in the study area. The causes of loss were physical injury during harvest, rotting and disease infection, lack of storage area and poor handling area. The discarded potato fetched no economic value to the retailers. The aggregate postharvest loss from production (farm get level) to consumption level is $24.88 \%$ (Table 7 ).

Table 5 Socio-demographic characteristics of traders (continuous variables). Source: own survey, 2017

\begin{tabular}{|c|c|c|c|c|c|c|}
\hline \multirow[t]{2}{*}{ Variables } & \multicolumn{2}{|c|}{ Local traders $(N=7)$} & \multicolumn{2}{|c|}{ Wholesalers $(N=5)$} & \multicolumn{2}{|c|}{ Retailers $(N=8)$} \\
\hline & Mean & SD & Mean & SD & Mean & SD \\
\hline Age & 31.43 & 2.82 & 29.13 & 3.682 & 35 & 6 \\
\hline Family size & 4.14 & 1.773 & 4.5 & 1.773 & 4 & 1.96 \\
\hline Experience & 2.71 & 1.704 & 2 & 1.165 & 4.2 & 1.67 \\
\hline Education & 8 & 1.915 & 2.63 & 1.408 & 8.4 & 1.48 \\
\hline Initial working capital [Birr] & 6500.14 & 2491.86 & 359.38 & 166.636 & 21,928 & 4657.781 \\
\hline Current working capital [Birr] & 59,000 & 62,804 & 3410.3 & 3279.721 & 65,034 & $14,761.95$ \\
\hline
\end{tabular}

Table 6 Socio-demographic characteristics of traders (categorical variables). Source: own survey, 2017

\begin{tabular}{|c|c|c|c|c|c|c|c|c|c|}
\hline \multirow[t]{2}{*}{ Variables } & \multicolumn{3}{|c|}{ Local traders $(N=7)$} & \multicolumn{3}{|c|}{ Retailers $(N=8)$} & \multicolumn{3}{|c|}{ Wholesalers $(N=5)$} \\
\hline & Description & Frequency & $\%$ & Description & Frequency & $\%$ & Description & Frequency & $\%$ \\
\hline \multirow[t]{2}{*}{ Gender } & Male & 7 & 100 & Male & 5 & 63 & Male & 5 & 100 \\
\hline & Female & 0 & 0 & Female & 3 & 38 & Female & 0 & 0 \\
\hline \multirow[t]{2}{*}{ Access to credit } & Yes & 0 & 0 & Yes & 0 & 0 & Yes & 0 & 0 \\
\hline & No & 7 & 100 & No & 8 & 100 & No & 5 & 100 \\
\hline
\end{tabular}

\footnotetext{
${ }^{1}$ The basic unit of money in Ethiopia; equal to 100 cents.
} 

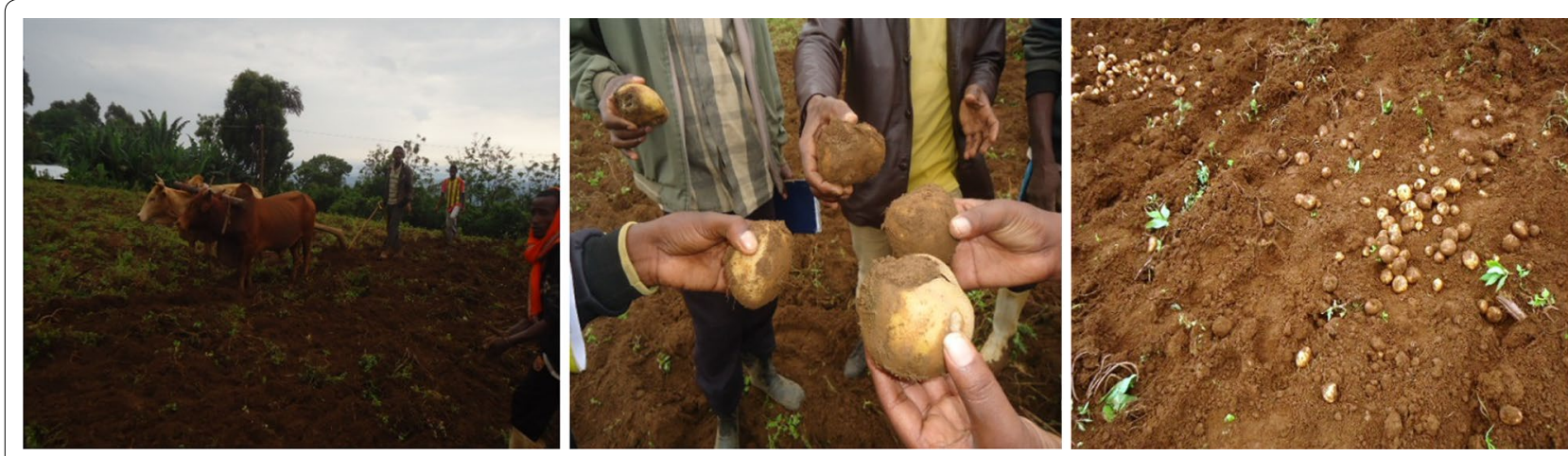

Fig. 2 Harvesting of potato by plowing the cultivated area

Table 7 Assessment of postharvest loss along potato value chain. Source: own survey, 2017

\begin{tabular}{lcccr}
\hline & Producer & Local trader & Wholesaler & Retailer \\
\hline $\begin{array}{c}\text { Postharvest loss in } \\
\text { quintal per year }\end{array}$ & 9.31 & 3.34 & 2.5 & 4.07 \\
$\begin{array}{c}\text { Postharvest loss in \% } \\
\text { per year }\end{array}$ & 21.72 & 0.59 & 0.65 & 1.92 \\
$\begin{array}{l}\text { Postharvest loss in } \\
\text { Birr per year }\end{array}$ & 3683.11 & 1324.64 & 1630.1 & 2856.03 \\
\hline
\end{tabular}

\section{Causes of postharvest losses at producer level Harvesting}

In Masha District, potato is harvested by different mechanisms. The first round potato is harvested by hand and suffers mechanical injury during harvest period because of digging tools, wooden sticks, hoes or forks. At the second round, producer collected remaining potato from the first round harvest by plowing potato cultivated area and/or digging via hoe. This kind of harvesting mechanisms leads the crop to damage due to injuries, cutting through or scraping away the outer skin of produce which provide entry points for molds and bacteria causing decay, increase water loss from the damaged area and cause an increase in respiration rate, and thus heat production finally hastens its senescence.

\section{Mechanical injury}

The high moisture content and soft texture of root crops like potato make them susceptible to mechanical injury, which occurred from production to retail marketing because of poor harvesting practices in the study area (Figs. 2, 3).

\section{Curing}

The producers in Masha Zone usually stayed their harvested potato without any shade at farm gate for 2-4 days due to low local market demand, and since the area is recognized by its heavy rainfall, the harvested potato was easily spoiled again. They did not cure their harvested product in the sided shade to get a quality product. One of the simplest and most effective ways to reduce water loss and decay during postharvest storage of root, tuber and bulb crops is curing after harvest. The type of wound also affects periderm formation: Abrasions result in the formation of deep, irregular periderm; cuts result in a thin periderm; and compressions and impacts may entirely prevent periderm formation. And also crops are most likely to be injured at harvest by the digging tools, which may be wooden sticks, machetes, hoes or forks. Researchers observed huge amount of potato thrown away or discarded at the farm gate; these all are neither consumed nor marketed in any form (Fig. 4).
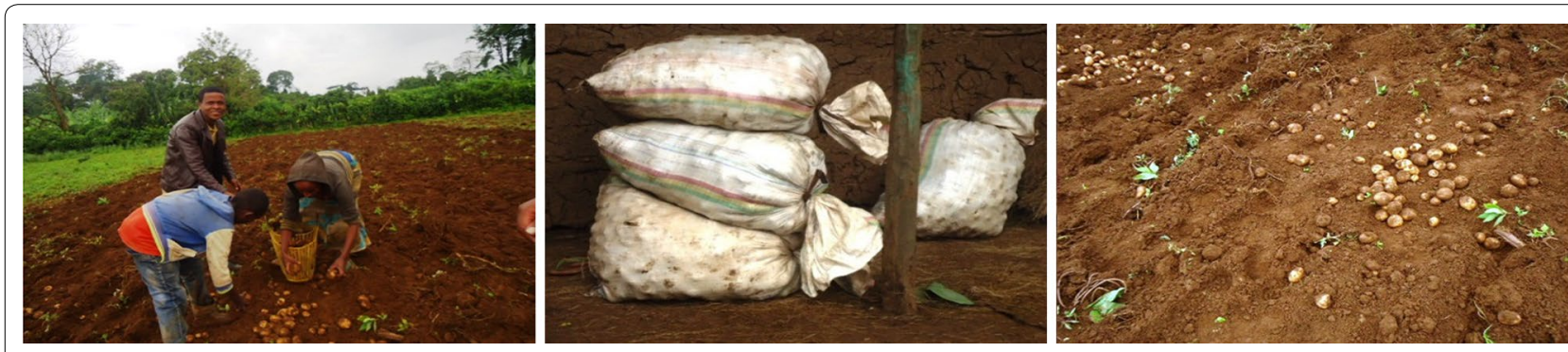

Fig. 3 Harvesting, collecting and storage habit of potato in the study area 

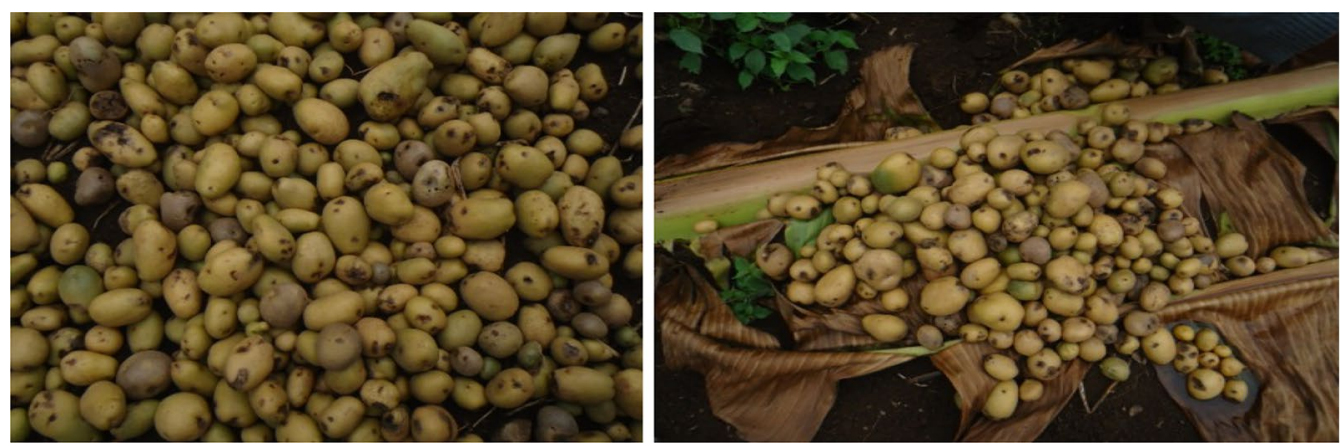

Fig. 4 Discarded potato at the farm gate

\section{Selection and grading}

All potatoes showing greening decay or severe damage owing to harvesting or pest attack should be discarded at harvest. Immature tubers and those showing minor damage or wetted by rain should be put aside for immediate consumption. Potatoes to be stored for food, or seed should be fully mature and free from any visible damage or decay. But in the study area the reality is different (Fig. 5).

\section{Storage}

The term "storage" as now applied to fresh produce is the holding of produces under controlled conditions. Usually in the study area, producers took the harvested potato to home if they had not get buyers and wait for sometimes until they get buyers and there is a chance to store potatoes for seed for subsequent production period. They place the produce directly on to the soil, especially wet soil, use dirty harvesting or field containers contaminated with soil, crop residues or decaying produce and dirty containers. There was paramount potato postharvest loss occurred due to improper and lack of storing area, insects and worms as well poor handling techniques. There are also situations where commission agents and traders collect potato together in open area around accessible load trucks from producers after bargained

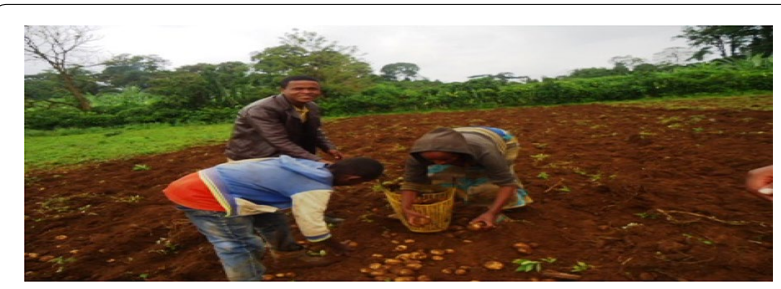

Fig. 5 Selection and grading of potato the selling price, but they promise to pay the price after it loaded. In this case, if traders face some hindering problems to load the collected potato, there is a probability to keep for 2-3 days while beaten by rainfall until it loaded. Significant amount of spoiled potato was observed due to these circumstances, and even sometimes traders refuse to take collected potato and free from losses. Commission agents are working for traders and/or wholesalers, and they never incur loss in potato marketing system (Fig. 6).

\section{Transportation}

The primary modes of transportation of potatoes in the study area to the markets were by loading it on back of animals like horses and donkeys. Due to over-packing or under-packing of field or marketing containers, careless handling, such as dropping or throwing or walking on produce and sitting on packed containers during the process of grading, transport or marketing, and the perish ability nature of potato, there is high postharvest loss (Fig. 7).

\section{Diseases}

Late blight caused by Phytophthora infestans was a major fungus disease in the study area causing huge yield losses. The climate is favorable for the development of late blight, particularly during the two rainy seasons. High costs of chemicals to control the disease limit the use of fungicides, particularly by small-scale farmers. Producers had weak habit of preventive applications of fungicides rather they often start spraying when the disease is already present in the field making control very difficult. Infested fields are then the source of inoculums (spores) for other fields, and in this way late blight can spread rapidly throughout the production areas. The situation is further aggravated by poor 

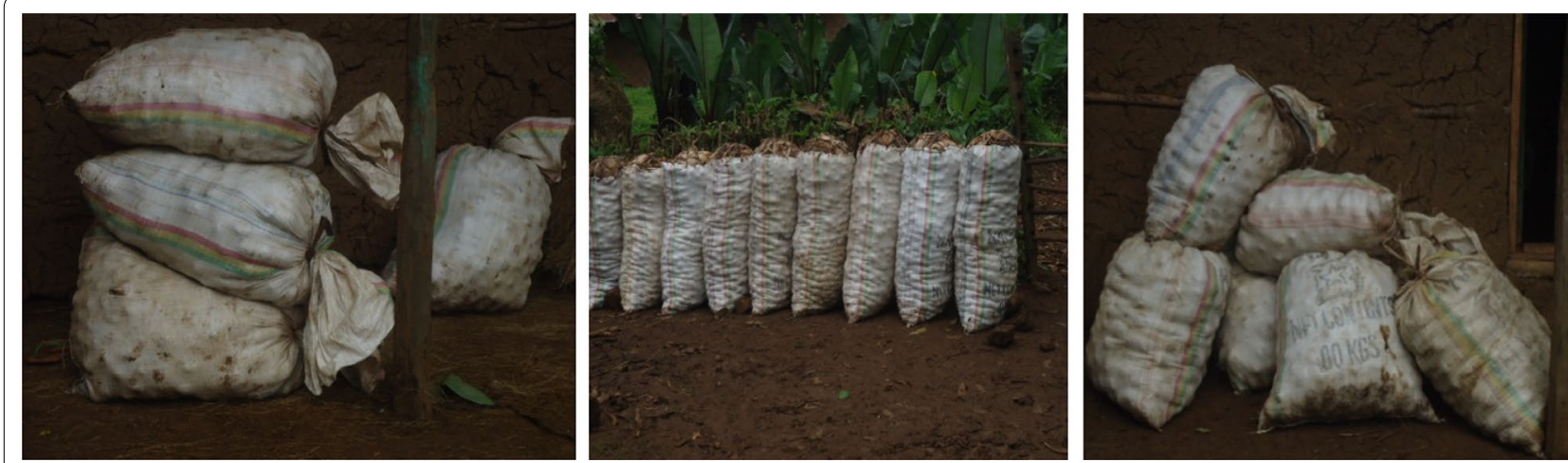

Fig. 6 Storing system in the study area
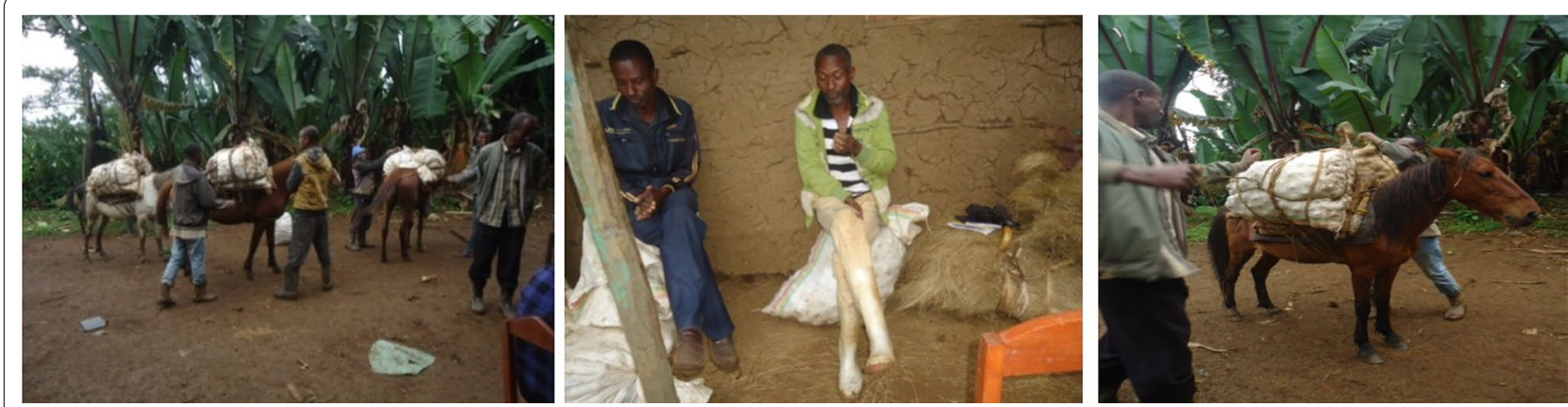

Fig. 7 Potato loading and unloading system in the study area

spraying techniques and the use of cheaper and less effective chemicals. Introducing varieties with some degree of resistance was important, but they still need fungicide applications to control the disease. It has been observed that late maturing varieties tend to have more resistance to late blight than early varieties, but farmers in the study area prefer early maturing varieties. It can be concluded that methods to control late blight are available, but they are not adequately applied by producers with limited resources for inputs and lack of knowledge (Fig. 8).

\section{Comparison between gross margin with loss and without loss in potato value chain}

The average gross margin with loss (6464.70 Birr) was less than the average gross margin without loss $(10,146.12$ Birr). This shows that postharvest losses reduce the income of farmers in the study area. The percentage loss of income incurred by the farmers was $36.3 \%$. The average gross margin with loss of local traders, wholesalers and retailers was 282,169.89, 219,644.61 and 345,826.36 Birr which was less than the average gross margin without loss which is indicated in Table 8.
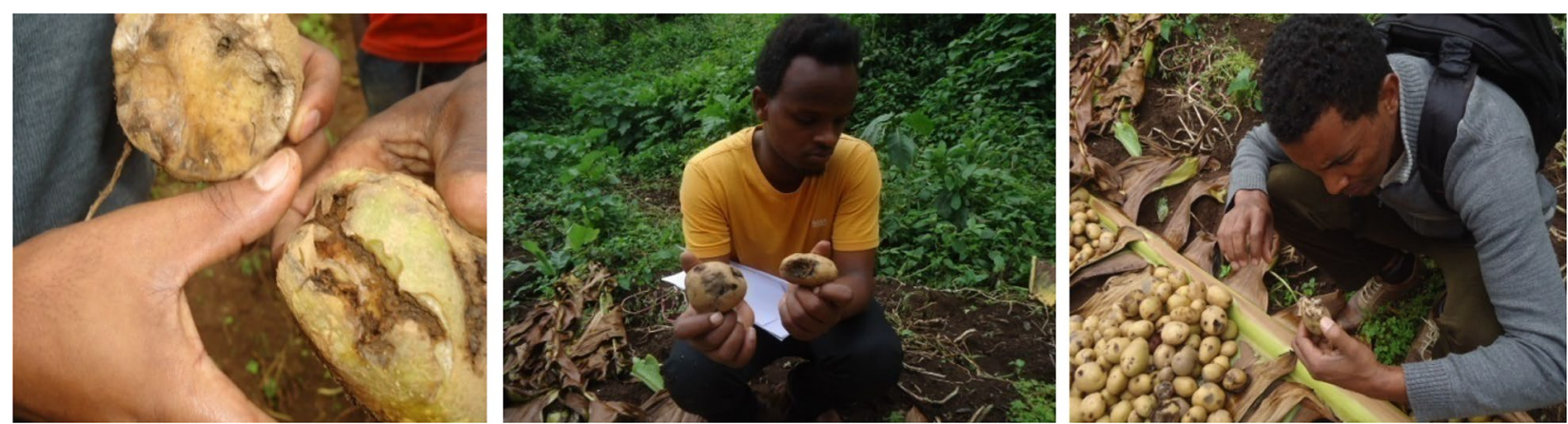

Fig. 8 Sample of potato lost due to disease 
Table 8 Gross margin with loss and without loss. Source: authors computation, 2017

\begin{tabular}{lccrr}
\hline & Producers & Local traders & Wholesalers & Retailers \\
\hline Total variable cost & $1,312,689.89$ & $210,979.52$ & $264,965.05$ & $163,190.01$ \\
Total revenue without loss & $3,270,888.61$ & $2,199,090.307$ & $1,813,887.84$ & $2,987,082.96$ \\
Total revenue with loss & $2,560,376.64$ & $2,186,168.733$ & $1,802,477.29$ & $2,929,800.82$ \\
Gross margin without loss & $1,958,198.72$ & $1,988,110.79$ & $1,548,922.8$ & $2,823,892.95$ \\
Gross margin with loss & $1,247,686.75$ & $1,975,189.213$ & $1,537,512.24$ & $2,766,610.81$ \\
Average margin without loss & $10,146.12$ & $284,015.83$ & $221,274.69$ & $352,986.62$ \\
Average margin with loss & 6464.70 & $282,169.89$ & $219,644.61$ & $345,826.36$ \\
\hline
\end{tabular}

\section{Determinants of postharvest loss}

Multiple linear regression model was used to assess factors that determine postharvest losses of potato at producer level in the study area. To exclude heteroscedasticity problem, we regress the variables by using robust but before running the regression we checked multicollinearity problem, and the result showed that there was no serious multicollinearity problem. Model is generally significant as given by the F coefficient and its probability. The $R$-squared is high showing that the explanatory variables explain about $81.9 \%$ of the variation in the dependent variable.

Out of 13 hypothesized variables, eight variables were found to determine postharvest loss of potato in the study area. These are sex (SEX), distance to the nearest market (DISFM), Experience (EXPR), and family size of working age (FMSZ), area allocated for potato (AOLP), total output (TOTP), selling price (PRICE) and access to credit (ACTC). Access to extension service (ACCEXT), improved seed (IMPSD), local seed (LOSD), age (AGE) and education level (EDUCL) were not significantly associated with dependent variable (Table 9).

The regression result of sex indicated that the variable had negative relationship with postharvest loss and significant at less than $10 \%$ significance level. This implies that female-headed households are likely to experience postharvest losses for these crops as compared to the male-headed households. The coefficient of the variable indicated that potato producer being a male should reduce potato postharvest loss by 1.914101 quintal. As similar to the hypothesis, Experience had negative effect on potato postharvest loss and was significant at $<10 \%$ probability level. The negative relationship between quantity lost and farm experience indicated that the increase in farm experience resulted in a decrease in quantity lost. The coefficient of the variable indicated that the increase in farm experience by 1 year resulted in a decrease in quantity lost by 0.0957481 quintal. The better postharvest handling practices also reduce postharvest loss of potato. Family size of working age was statistically significant at $<1 \%$ significance level. As expected, the variable has a negative effect on quantity postharvest lost of potato. The negative and significant relationship indicates that as potato production was labor-intensive activity, larger number of working age family size provides higher labor force to undertake potato production and postharvest handling activities. The coefficient of the variable indicated that the increase in one number of working age family size reduced quantity postharvest by 2.249992 quintal or the decrease in one number of working age family size increased quantity postharvest loss by 2.249992 quintal. Distance to nearest market had positive effect on potato postharvest loss and found to be statistically significant at $<1 \%$ significance level. The positive relationship indicates that the farther is a household from the market, farmers

Table 9 Determinants of losses at producer level. Source: own survey, 2017

\begin{tabular}{|c|c|c|c|c|c|}
\hline \multicolumn{6}{|c|}{$\begin{array}{l}\text { Number of obs. }=193 \\
F(13,179)=122.33 \\
\text { Prob }>F=0.0000 \\
R \text {-squared }=0.8191 \\
\text { Root } M S E=3.8426\end{array}$} \\
\hline \multirow[t]{2}{*}{ Qlost } & & \multicolumn{4}{|l|}{ Robust } \\
\hline & & Coeff. & SE & $T$ & $P>t$ \\
\hline AGE & $0.031,197$ & 0.031197 & 0.0316204 & 0.99 & 0.325 \\
\hline SEX & -1.914101 & -1.914101 & 1.039497 & -1.84 & 0.067 \\
\hline EDUCL & -0.0597035 & -0.0597035 & 0.0878469 & -0.68 & 0.498 \\
\hline DISFM & 0.6984369 & 0.6984369 & 0.1966846 & 3.55 & 0.000 \\
\hline EXPR & -0.0957481 & -0.0957481 & 0.0539875 & -1.77 & 0.078 \\
\hline FMSZ & -2.249992 & -2.249992 & 0.4184121 & -5.38 & 0.000 \\
\hline AOLP & 1.118513 & 1.118513 & 0.3593258 & 3.11 & 0.002 \\
\hline TOTP & 0.1334658 & 0.1334658 & 0.0194476 & 6.86 & 0.000 \\
\hline PRICE & -0.0130786 & -0.0130786 & 0.0066856 & -1.96 & 0.052 \\
\hline LOSD & 0.2912362 & 0.2912362 & 0.746762 & 0.39 & 0.697 \\
\hline IMPSD & -0.7174505 & -0.7174505 & 1.215861 & -0.59 & 0.556 \\
\hline ACTC & -2.845566 & -2.845566 & 1.454018 & -1.96 & 0.052 \\
\hline ACCEXT & 0.6302327 & 0.6302327 & 0.8539101 & 0.74 & 0.461 \\
\hline _cons & & 20.605 & 4.538065 & 4.54 & 0.000 \\
\hline
\end{tabular}


forced to transport or store their product and it leads to potato postharvest loss. The coefficient of the variable indicated that the increase in distance of market by $1 \mathrm{~km}$ resulted in a decrease in potato postharvest loss by 0.6984369 quintal. Area allocated for potato production was significant at $<1 \%$ significance level, and as expected it had a positive relationship with quantity of potato postharvest loss. The coefficient of the variable illustrated that the increase in 1 ha of area allocated for potato production resulted in 1.118513 quintal of quantity of potato postharvest loss. Total output was statistically significant at $<1 \%$ significance level and had positive effect on quantity of potato postharvest loss. The coefficient of the variable showed that the increase in the total output of potato by 1 quintal increased quantity postharvest of potato by 0.1334658 quintal. Selling price of potato was significant at 5\% significance level. As hypothesized, it had negative effect on quantity postharvest loss of potato. The coefficient of the variable indicated that the increase in selling price of potato resulted in the decrease in quantity of potato postharvest lost by 0.0130786 Birr. Access to credit was significant at 5\% significance level and had negative effect on quantity of postharvest lose. The coefficient of the variable indicated that access for credit resulted in 2.845566 quintal of potato postharvest loses.

\section{Discussion}

The average age of interviewed respondents was 37.6632 years. The result indicates a good supply of agile workforce in potato production in the study area. This result is in line with finding of Ayandiji et al. [24]. Babalola et al. [29] argued that age is a very important demographic characteristic because it determines the size and quality of the labor force. Older farmers are expected to use their farming experience to decide on appropriate postharvest handling practices and hence an overall reduction in postharvest losses [30].

The descriptive result indicated that the mean value of the amount of potato postharvest loss at producer level was 9.31 qt per year per household which means $21.72 \%$. Postharvest losses in fruits and vegetables are about $25-40 \%$ [31]. 75\% losses were occurred at field level [32]. $30 \%$ of fruits, $10 \%$ of vegetables, $50 \%$ of root crops and $60 \%$ of cash crops were lost [33]. The results are in line with reports of Admassu [34], Abebe and Bekele [35] and Humble and Reneby [36]. According to Hodges et al. [9], postharvest losses in developing countries can range from 15 to $50 \%$. Horticultural crops are perishable products, and they are more prone to greater losses than for non-perishable crops [4]. Postharvest losses at producer level occur due to harvesting injuries; for example, for the first round potato is harvested by hand and some simple digging material and at this stage loss could occur. At the second round, producers collect potato output remained from the first round harvest; hence, they plow potato cultivated area and/or dig via hoe. These potato harvesting mechanisms trigger potato loss at farm gate level. In addition to this, after harvested usually potato stayed at farm gate for 2-4 days due to lack of potato market demand in the area without any shade, and since the area is recognized by its heavy rainfall, the harvested potatoes were easily spoiled again. Researchers observed huge amount of potatoes thrown away or discarded fruits at the farm gate; these all are neither consumed nor marketed in any form. Estimated losses at farm, market and consumption level were reported as 38.6, 35.9 and $25.5 \%$ of the total losses, and total postharvest losses were $31 \%$ of the total production [31]. Martey et al. [37] found that about $75 \%$ of the total postharvest losses occurred at the farm level and about $25 \%$ at the market level.

Next to producer, postharvest loss of potato was higher at retailer level in the study area. Losses at retailer level are obvious because he is unaware about the daily sales and he buys potato according to his experience and bears losses in shape of unsold quantity. In the study area, retailers lack shops for performing their activities and they sell potato in the market place which is exposed to sunlight. Bari [31], FFTC [38], Liu [39] also indicate that unsold quantity was lost daily and also retailers don't have enough resources to store their unsold commodity. These results are also similar to FFTC [38] and Gajanana et al. [40]. Postharvest losses reduce the income of farmers in Masha District of southwest Ethiopia. This result is in line with the finding of Ayandiji et al. [24]. The average gross margin with loss was less than the average gross margin without loss for all potato value chain actors. The factors that influence the postharvest losses significantly at the farm level were identified in the study area.

The regression result of sex indicated that the variable had negative relationship with postharvest loss and significant at $<10 \%$ significance level. Married household heads are thought to have an advantage with regards to labor availability for their production and postharvest handling activities, which in turn could minimize postharvest losses [41]. Takane [42] contented that usually single-headed households are female-headed households, and because of the absence of husbands, female-headed households have fewer economically active household members and are in a disadvantageous position relative to their male-headed counterparts in deploying family labor for farm activities. Smallholder farmers find themselves at a major disadvantage because many do not understand the market well, how it works and why prices fluctuate, they have little or no information about market conditions and prices, they are not organized collectively, 
and they have no experience of market negotiation [43]. There is therefore a need for these farmers to be made aware of various products they can grow in relation to their climatic conditions and market demand [44]. Maleheaded households are likely to experience postharvest losses for these crops as compared to the female-headed households. This result contradicts the finding of Liu [39] who concluded that female farmers were found to be more prone to high levels of losses than their male counterparts. A study conducted by Ortmann and King [41] revealed a positive and statistically significant relationship between sex of household head and both cabbage and spinach postharvest losses. Considering the fact that more time and careful handling are required to minimize mechanical damages in leafy and fruit vegetables, females are likely to encounter minimal losses since they are careful handlers and are considered to be more patient as compared to their male counterparts.

The education levels of respondents in the study areas were generally low (mean of 5.3990 years of schooling). This finding is consistent with the finding of Ortmann and King [41]. Education is the key in understanding consumer quality expectations in niche markets which is necessary also because consumers may have different expectations and acceptance of the same food product produced using different technologies [45]. The more educated the farmer, the less will be potato postharvest loss. It has had positive effect on the adoption of appropriate agricultural technologies and skills to the farming population over the years. This agrees with the findings of Oduekun [45] that the level of education influences participation in agricultural productive activities, adoption, transfer and application of innovations. This could be a contributory factor to the high postharvest losses in potato production in the study areas because only farmers with good education often appreciate and use most postharvest technologies available. This result is consistent with the findings of Fawole and Fasina [46], Basavaraja et al. [47], Adesina and Baidu-Forson [48]. Education level of farmers also had significant impact on postharvest losses [37].

As potato production was labor-intensive activity, larger number of working age family size provides higher labor force to undertake potato production and postharvest handling activities. This is because farmers who had larger household sizes tended to have lower levels of postharvest losses because they have relatively high amount of family labor. Distance from the farm to the market was positively and significantly related to tomato postharvest losses. Similar results were reported by Liu [30].

On average, producer households had 7.0415 years of experiences in potato production and marketing. As similar to the hypothesis, Experience had negative effect on potato postharvest loss and was significant at $<10 \%$ probability level. More experienced farmers are expected to have minimal postharvest losses as compared to the inexperienced ones since they can utilize the gained experience to make important handling decisions as well as having market contacts to ensure that harvested produce is sold quickly [41]. The research result implied that as the farmer become more experienced, postharvest losses diminish. An experienced farmer population implies good knowledge and adoption of postharvest handling technology among the farmers [30]. As revealed by [41], older household heads have farming experience and adopted new technologies than young farmers; therefore, farming experience was expected to have a negative relationship with postharvest losses. Farming experience is thought to positively influence technology adoption $[37,49]$.

The mean distance from the nearest market center of producers in the study area was $5.5026 \mathrm{~km}$. Distance to nearest market had positive effect on potato postharvest loss and found to be statistically significant at $<1 \%$ significance level. PHLs also varied depending upon the distance to the market. This pushes to higher quantity of potato postharvest loss. When they are marketed to medium-distance markets, PHLs were $5.15 \%$, whereas for long-distance markets they were $8.17 \%$ [50]. According to Ortmann and King [41], the distance between the farm and the market had a positive and statistically significant relationship with cabbage and tomato postharvest losses. The farther the market is from the farm, the longer it takes for the produce to reach the market and hence an increase in postharvest losses due to heat buildup and in transit mechanical injuries [4]. According to Ayandiji et al. [24], increase in the distance from the farm to the market will increase the quantity of fruit loss; this is because the longer the distance of the farm to the market, the longer the time it will take for the produce to get to the market, and so the losses will increase because of the congestion and packaging of the tomato together for a long time. The longer the distance the more the time it will take for the produce to get to the market and so, the losses will increase because of congestion of the product and build up of heat [30].

From the total land owned by the respondent, the land allocated for potato production is $0.55 \mathrm{ha}$ /household (i.e., $27.94 \%$ of total farmland). Area allocated for potato production was significant at $<1 \%$ significance level, and as expected it had a positive relationship with quantity of potato postharvest loss. When the area for production increases, total output will increase and also it will increase potato postharvest loss. Higher land holdings serve as an incentive to produce surplus for markets [42]. 
With respect to postharvest losses, large land holdings imply large volumes being produced, and the higher the production volumes, the higher the losses since farmers face the constraints of poor handling practices and limited storage facilities $[30,43]$. The larger the area put into cultivation leads to higher production and greater chance of losses due to poor handling and lack of proper storage [41]. The larger the farm size, the higher the likelihood for postharvest losses. Similar results were reported by Gajanana [40] and Ortmann and King [41]. They reported that as production scale increases farmers will have to contend with the problem of storage and transportation; and where these facilities are not adequate, losses are imminent. The larger the area put into cultivation, the higher the quantity harvested and chances of losses due to poor handling and lack of proper storage [30]. Takane [42], however, argued that farm size may have indirect positive impacts on market participation by enabling farmers to generate production surpluses and overcome credit market, thus reducing postharvest losses. Overall, an increase in farm size tends to have a significant increase in tomato postharvest losses [41]. According to the same source instead of increasing farm size or land allocated to tomatoes, reducing the farm size or land allocated to tomatoes has an overall effect of tomato postharvest loss reduction. The larger the area put into cultivation the higher the quantity harvested and chances of higher losses due to poor handling and lack of proper storage. Good hygiene practices such as hand washing and postharvest handling equipment washing minimize chances of produce contamination, hence a reduction in postharvest losses [4]. This was in line with study of Begum et al. [51] which was studied with the title of Economic Analysis of Postharvest Losses in Food Grains for Strengthening Food Security in Northern Regions of Bangladesh. Increase in the number of baskets harvested of fruits also results in increase in the losses because there is no effective method of storage; hence, the more the quantity of harvested produce, the more the spoilage [24].

\section{Conclusion}

The descriptive result of assessment of postharvest losses along potato value chain actors indicated that $21.72,0.59,0.655$ and $1.92 \%$ loss was estimated at producer, local trader, wholesaler and retailer levels, respectively. The average gross margin with loss of producers, local traders, wholesalers and retailers was 6464.70, 282,169.89, 219,644.61 and 345,826.36 Birr which was less than the average gross margin without loss (10,146.12, 284,015.83, 221,274.69 and 352,986.62 Birr). Out of suggeted variables sex, distance to the nearest market, experience, and family size of working age, area allocated for potato, total output, selling price and access to credit. Farmers in the study area lack skills of pre- and postharvest management and disease prevention of potato. Therefore, training on cultivation, disease prevention and pre- and postharvest management are important factors for enhancement of potato productivity and reducing postharvest losses in the study area. In the study areas, lack of storage facilities for potato was raised by farmers and other actors as a priority problem. There is the need for provision of good storage facilities to store the produce that are harvested before they are taken to the market. This will help to reduce the losses that occur at the farm level. Therefore, it is recommended to expand DLS in high potato-producing areas as per standard DLS design and construction. Through technical support to the farmers, cost effective mechanism of expanding DLS should be considered. Postharvest technology should be introduced to reduce the losses. In the potato market survey, it was observed that potato is transported over long distance either spread on floor of the truck, back of horse or put in congested sacks. During loading and unloading, there is mishandling of the products which lead to quick spoilage and high loss. Therefore, it is important to establish potato transportation standards and enforce it. There should be ready market for the produce. The markets must be well organized and also the road network must be improved in order to aid easy transportation of their produce. Roads linking farms to market should be improved to reduce transit losses. Establishment of farmers market and cooperative marketing should be encouraged to reduce losses related to marketing functions.

\section{Abbreviations}

PHLs: postharvest losses; DLS: diluted light storage; ETB: Ethiopian Birr; SNNPR: Southern Nation Nationalities and Peoples Region.

\section{Authors' contributions}

The corresponding author carried out the responsibilities of proposal writing, data collection and preparation of the manuscript. The co-authors FB and LWM were participated in activities like communicating with the donors, commenting on issues to be raised on the proposal and questioner preparation and participating in the write-up of the manuscript. All authors read and approved the final manuscript.

\section{Author details \\ ${ }^{1}$ College of Agriculture and Natural Resources, Department of Agro Econom- ics, Mizan-Tepi University, Mizan-Aman, Ethiopia. ${ }^{2}$ College of Agriculture and Natural Resources, Department of Natural Resource Economics, Mizan- Tepi University, Mizan-Aman, Ethiopia. ${ }^{3}$ College of Agriculture and Natural Resources, Department of Horticulture, Mizan-Tepi University, Mizan-Aman, Ethiopia.}

\section{Acknowledgements}

This study received financial support from Mizan-Tepi University. DAs and government office workers of Masha District are acknowledged for their cooperation during the data collection.

\section{Competing interests}

The authors declare that they have no competing interests. 


\section{Availability of supporting data}

We declare that whatever data have been used in the manuscript, it can be made available to anyone who desires to see them from the corresponding author on request.

\section{Consent for publication}

We agreed that the information given in the manuscript now can be published by the Publication House and Journal of "Agriculture and Food Security."

\section{Ethical approval and consent to participate}

It is to declare that we have all the ethical approval and consent to take participate in research paper writing and submission to any relevant journal from our organization where we are working and posted.

\section{Funding}

This work was funded by Mizan-Tepi University from its research and community service budgets.

\section{Publisher's Note}

Springer Nature remains neutral with regard to jurisdictional claims in published maps and institutional affiliations.

Received: 18 April 2017 Accepted: 6 January 2018

Published online: 11 March 2018

\section{References}

1. Nicholas H, Nisar M, James D. A review of emergency food security assessment in Ethiopia. Humanitarian policy group report, a study commissioned by and prepared for the World Food Programme, Rome. 2006.

2. FAO. How to feed the world in 2050. Rome: FAO; 2009.

3. Dercon S, Krishnan P. Vulnerability, seasonality and poverty in Ethiopia. J Dev Stud. 2015;36(6):25-53.

4. Kader AA. Increasing food availability by reducing postharvest losses of fresh produce. In: V international postharvest symposium, vol. 682. 2005 p. 2169-76.

5. Parfitt J, Barthel M, Macnaughton S. Review_food waste within food supply chains: quantification and potential for change to 2050. Philos Trans R Soc B Biol Sci. 2010;365(1554):3065-81.

6. Victor K. Post-harvest losses and strategies to reduce them. Technical paper on post harvest losses. Action Contre la Faim (ACF), member of ACF International. 2014. p. 2-25

7. FAO/World Bank Work. Food and Agricultural Organization of the United Nations. Reducing post-harvest losses in grain supply chains in Africa: lessons learned and practical guidelines. FAO/World Bank Work. FAO Headquarters 18-19 Mar 2010, Rome, Italy. 2010.

8. Jayne TS, Mather D, Mghenyi E. Principal challenges confronting smallholder agriculture in sub-Saharan Africa. World Dev. 2010;38(10):1384-98.

9. Hodges RJ, Buzby JC, Bennett B. Foresight project on global food and farming futures: postharvest losses and waste in developed and less developed countries: opportunities to improve resource use. J Agric Sci. 2011:149:37-45

10. FAO. IFAD (2012) The State of Food Insecurity in the World 2012: economic growth is necessary but not sufficient to accelerate reduction of hunger and malnutrition. Rome: FAO; 2014.

11. Ayalew T, Paul CS, Hirpa A. Characterization of seed potato (Solanum tuberosum L.) Storage, pre-planting treatment and marketing systems. The case of West Arsi. Afr J Agric Res. 2014;9(15):1218-26.

12. Devaux A, Kromann P, Ortiz O. Potato for sustainable global food security. Potato Res. 2014;57:185-99.

13. CSA (Central Statistical Authority). Agricultural sample survey 2015/16. Volume $V$. Report on area and production of major crops for private peasant holdings, meher season. Statistical Bulletin 578, Central Statistical Agency, Addis Ababa, Ethiopia. 2016. p. 10-19.

14. Haverkort AJ, Koesveld MJ, van Schepers HTAM, Wijnands JHM, Wustman R, Zhang XY. Potato prospects for Ethiopia: on the road to value addition. Lelystad: PPO-AGV (PPO publication 528). The Netherlands. 2012. p. 1-66.

15. Beliyu L, Tederose T. Knowledge gap in potato technologies adoption: the case of Central Highlands of Ethiopia. J Agric Ext Rural Dev. 2014;6(8):259-66.
16. Berhanu M, Getachew W. The role of local innovations to promote improved technologies: the case of potato farmers research groups (FRGs) in Jimma and Illubabor Zones, South Western Ethiopia. E3 J Agric Res Dev. 2014;4(3):39-49.

17. Vita and IPF (Irish Potato Federation). Potatoes in development: a model of collaboration for farmers in Africa. Pdf doc. 2014

18. Tesfaye A. Potato production manual. Amharic Version printed in 1999 Ethiopian Calendar. 2008

19. Mulatu E, Ibrahim OE, Bekele E. Policy changes to improve vegetable production and seed supply in Hararghe, Eastern Ethiopia. J Veg Sci. 2005;11(2):81-106.

20. Gildemacher P, Kagnongo W, Ortiz O, Tesfaye A, Woldegiorgis G, Wagoire W, Kakuhenzira R, Kinyae P, Nyongesa M, Struik PC. Improving potato production in Kenya, Uganda and Ethiopia: a system diagnosis. Potato Res. 2009;52:173-205.

21. Tewari VK, Ashok Kumar A, Kumar SP, Nare B. Farm mechanization status of West Bengal in India. J Agric Sci Rev. 2012;1(6):139-46.

22. BoFED (Bureau of Finance and Economic Development). Annual statistics for Amhara National Regional State. Bahir Dar, Ethiopia. 2007.

23. Hakan K. Design and management of postharvest potato (Solanum tuberosum L.) storage structures. Ordu Univ J Sci Technol. 2012;2(1):23-48.

24. Ayandiji A, Adeniyi OR, Omidiji D. Determinant Post harvest losses among tomato farmers in Imeko-Afon Local Government Area of Ogun State, Nigeria. 2011.

25. Babalola DA, Agbola PO. Impact of malaria on poverty level: evidence from rural farming households in Ogun State, Nigeria. Babcock J Econ Finance. 2008;1(1):108-18.

26. Oyekanmi MO. Determinants of postharvest losses in tomato production: a case study of Imeko-Afon Local Government Area of Ogun State. Unpublished B.Sc. thesis, Department of Agriculture, Babcock University. 2007

27. Addo JK, Osei MK, Mochiah MB, Bonsu KO, Choi HS, Kim JG. Assessment of farmer level postharvest losses along the tomato value chain in three agro ecological zones of Ghana. 2015. p. 338-344.

28. Greene WH. Econometric analysis. 5th ed. London: Prentice Hall Inc; 2003.

29. Babalola DA, Makinde YO, Omonona BT, Oyekanmi MO. Determinants of post-harvest losses in tomato production: a case study of Imeko-Afon local government area of Ogun State. J Life Phys Sci. 2010;3(2):14-8.

30. Maremera G. Assessment of vegetable postharvest losses among smallholder farmers in Umbumbulu area of Kwazulu-Natal Province, South Africa. MSc Thesis, 2014

31. Bari A. Economic assessment of post-harvest losses of mango in Multan and Rahim Yar Khan Districts. A postgraduate research thesis in department of Agricultural Economics, University of Agriculture Faisalabad. 2004

32. Kisaka-Lwayo M. Risk preferences and consumption decisions in organic production: the case of KwaZulu-Natal and Eastern Cape Provinces of South Africa, PhD Dissertation, 2012.

33. Mezgebe AG, Terefe ZK, Bosha T, Muchie TD, Teklegiorgis Y. Post-harvest losses and handling practices of durable and perishable crops produced in relation with food security of households in Ethiopia: secondary data analysis. J Stored Prod Postharvest Res. 2016:7(5):45-52.

34. Admassu S. Post-harvest sector challenges and opportunities in Ethiopia. Addis Ababa: Ethiopian Agricultural Research Organization; 2005.

35. Abebe HG, Bekele H. Farmers' post-harvest grain management choices under liquidity constraints and impending risks: implications for achieving food security objectives in Ethiopia. Poster paper presentation, International Association of Agricultural Economists Conference, Gold Coast, Australia. 2006

36. Humble S, Reneby A. Post-harvest losses in fruit supply chains - a case study of mango and avocado in Ethiopia. Karin Hakelius, Swedish University of Agricultural Sciences, Department of Economics. 2014

37. Martey E, Al-Hassan RM, Kuwornu JKM. Commercialization of smallholder agriculture in Ghana: a Tobit regression analysis. Afr J Agric Res. 2012:7(14):2131-41.

38. FFTC. Post-harvest losses of fruits and vegetables in Asia, an international information centre for farmers in the Asia Pacific Region. 1993. http:// www.fftc.agnet.org/library.php?func=view\%26id $=20110630151214$. Accessed 12 May 2017.

39. Liu FW. Post-harvest handling of horticultural crops in Asia. Department of Horticulture, National Taiwan University. 1990. 
40. Gajanana TM, Sudha M, Saxena AK, Dakshinamoorthy V. Post-Harvest handling, marketing and assessment of losses in papaya. In: ISHS Acta Horticulturae, 851: II international symposium on papaya, 2008. 2008.

41. Ortmann GF, King RP. Research on agri-food supply chains in Southern Africa involving small-scale farmers: current status and future possibilities. Agrekon. 2010;49(4):397-417.

42. Takane T. Labour use in smallholder agriculture in Malawi: six village case studies. Afr Study Monogr. 2008;29(4):183-200.

43. Magingxa LL, Alemu ZG, Van Schalkwyk HD. Factors influencing access to produce markets for smallholder irrigators in South Africa. Dev South Afr. 2009;26(1):47-58

44. Thamaga-Chitja J, Hendriks SL. Emerging issues in smallholder organic production and marketing in South Africa. Dev South Afr. 2008;25(3):317-26.

45. Oduekun FK. Factors affecting the adoption of improved rice production package in Obafemi/Owode and Ifo LAG's of Ogun State. M.Sc. thesis, Department of Agricultural Extension Services, University of Ibadan. 1991.

46. Fawole $O P$, Fasina $O$. Factors predisposing farmers to organic fertilizer uses in Oyo state, Nigeria. J Rural Econ Dev. 2005;14(2):81-90.
47. Basavaraja H, Mahajanshetti SB, Udagatti NC. Economic analysis of postharvest losses in food grains in India: a case study of Karnataka. Agric Econ Res Rev. 2007;20:117-26.

48. Adesina AA, Baidu-Forson J. Farmers' perception and adoption of new agricultural technology: evidence from analysis in Burkina Faso and Guinea, West Africa. Am J Agr Econ. 1995;13:1-9.

49. Gangwar LS, Singh D, Singh DB. Estimation of post-harvest losses in Kinnow Mandarin in Punjab using a modified formula. Agric Econ Res Rev. 2007;20(2):315-31.

50. Kereth GA, Lyimo M, Mbwana HA, Mongi RJ, Ruhembe CC. Assessment of post-harvest handling practices: knowledge and losses of fruits in Bagamoyo district of Tanzania. Food Sci Qual Manag. 2013, p. 8-15.

51. Begum EA, Hossain MI, Papanagiotou E. Economic analysis of post-harvest losses in food grains for strengthening food security in Northern Regions of Bangladesh. Int J Appl Res Bus Adm Econ. 2012;01(03):1839-8456.

\section{Submit your next manuscript to BioMed Central and we will help you at every step:}

- We accept pre-submission inquiries

- Our selector tool helps you to find the most relevant journal

- We provide round the clock customer support

- Convenient online submission

- Thorough peer review

- Inclusion in PubMed and all major indexing services

- Maximum visibility for your research

Submit your manuscript at www.biomedcentral.com/submit 